\title{
Heat and power storage using aluminium for low and zero energy buildings
}

\author{
Mihaela Dudita ${ }^{1, *}$, Meryem Farchado ${ }^{1}$, Alexander Englert ${ }^{2}$, Dani Carbonell Sanchez ${ }^{1}$, and Michel Haller ${ }^{1}$ \\ ${ }^{1}$ SPF Institute for Solar Technology, HSR University of Applied Sciences Rapperswil, Switzerland \\ ${ }^{2}$ UMTEC Institute for Environmental and Process Engineering, HSR University of Applied Sciences Rapperswil, Switzerland
}

\begin{abstract}
A new concept for seasonal energy storage (both heat and power) for low and zero energy buildings based on an aluminium redox cycle $\left(\mathrm{Al} \rightarrow \mathrm{Al}^{3+} \rightarrow \mathrm{Al}\right)$ is proposed. The main advantage of this seasonal energy storage concept is the high volumetric energy density of aluminium $\left(21 \mathrm{MWh} / \mathrm{m}^{3}\right)$, which exceeds common storage materials like coal. To charge the storage, oxidized aluminium $\left(\mathrm{Al}^{3+}\right)$ is reduced to elementary aluminium (Al) in a central processing plant using renewable electricity in summer. In winter, during discharging process, the energy stored in aluminium is released in form of hydrogen and heat via the aluminium - water reaction. Hydrogen is directly converted to electricity and heat in a fuel cell. The discharging phase has been investigated using a laboratory-scale experimental setup. In optimized conditions, heat and hydrogen is reliably produced for all types of aluminium forms (grit, pellets, foil). A high efficiency of the conversion to hydrogen was obtained $(>95 \%)$. The remaining challenge is to optimize the entire cycle, e.g. the aluminium recovery process via the use of climate-neutral inert electrodes.
\end{abstract}

\section{Introduction}

The EU goal to cut greenhouse gas emissions by $80-95 \%$ by 2050 requires a new energy system. Besides more energy efficient products, about two third of the energy should be provided by renewables. Electricity production needs to be almost emission-free [1].

According to Eurostat, buildings are responsible for $38 \%$ of energy consumption and thus for a high amount of $\mathrm{CO}_{2}$ emissions [2]. A substantial increase of using renewable energy sources for heat and electricity production in buildings is required. Future buildings will need to be low/zero energy buildings. While the electricity demand of a central European country like Switzerland is rather constant during the year, the heat demand is much higher in wintertime (Fig. 1). Thus, seasonal thermal energy storage is needed for future buildings.

Photovoltaic (PV) and heat pump systems in combination with short-term electric and thermal storage and intelligent control are able to provide $50 \%$ of the electricity and heat consumption of a new building on-time and on-site, i.e without exchange with the electricity grid and thus without net-balancing over the year [3]. At the same time, these systems generate a surplus of electricity in summer that could cover the missing energy in winter. However, for covering the heat demand all over the year, an economic seasonal energy storage would be needed to store the heat and/or electricity from summer to wintertime (Fig. 2). Large scale seasonal thermal energy storage in combination with solar thermal collectors are able to cover up to
$100 \%$ of the heating demand of single- and multi-family buildings for all seasons [4, 5]. However, the large volumes needed for thermal energy storage are limiting the multiplication potential for this concept in denser populated areas or zones with high cost of built volume and of real estate.

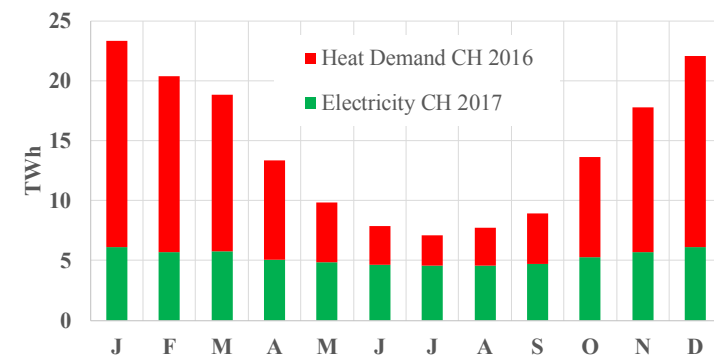

Fig. 1. Monthly heat and electricity demand, example from a Central Europe country - Switzerland $(\mathrm{CH})$.

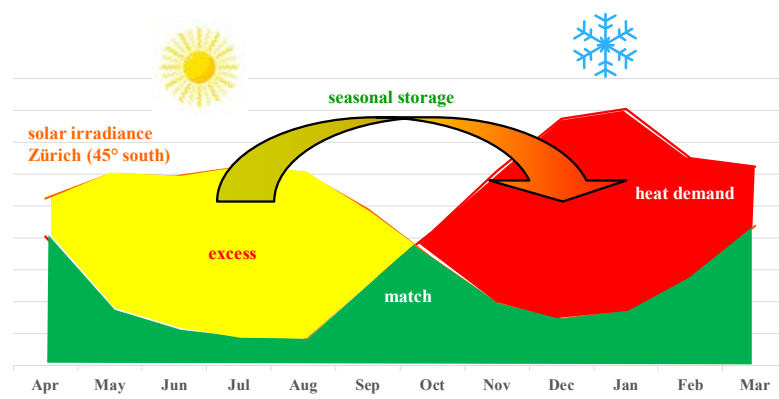

Fig. 2. Seasonal energy storage needed to cover heating demand with $100 \%$ solar energy all year around, for a Central European climate (Zürich, Switzerland).

* Corresponding author: mihaela.dudita@,hsr.ch 
Energy can also be stored in hydrogen, as shown for example in the "The house of the future", a multi-family house in Brütten (canton Zürich, Switzerland). The electricity and heat demand of this building is covered entirely with a combination of photovoltaics, thermal storage in water and in the ground, batteries and hydrogen tanks [6]. However, the storage volumes are quite large ( $>10 \mathrm{~m}^{3}$ per apartment). Moreover, hydrogen transport and storage is costly and involves special safety measures due to explosion hazards. One of the possible solutions to this problem would be the production of hydrogen directly on-site and at the time of consumption, thus avoiding large storage phases and volumes.

Hydrogen and fuel cells can provide electricity and heat with an environmentally friendly process that produces only water as by-product, converting chemical into electrical energy with high performance [7]. The "waste" heat from the fuel cell can be harnessed and used for building heating and domestic hot water, boosting the system efficiency. If hydrogen is produced from a carbon-neutral source, then buildings can be supplied with carbon-emission-free energy.

\subsection{Production of hydrogen from aluminium}

Hydrogen can be produced from the reaction of certain metals with water. Among these, aluminium and its alloys have been recognized as one of the most suitable material for hydrogen production [8]. The methods for using aluminium as a hydrogen source have been reviewed by several researchers $[8,10]$. There is an increasing interest in hydrogen generation from aluminium - water reaction for fuel cell applications [9].

Aluminium can react with water to form hydrogen and different hydrated aluminium based compounds (Eq. 1-3). All reactions are highly exothermic. Aluminium hydroxide $\mathrm{Al}(\mathrm{OH})_{3}$ is the stable reaction product until $280{ }^{\circ} \mathrm{C}(1)$. Aluminium oxide hydroxide $\mathrm{AlO}(\mathrm{OH})(2)$ is the stable form in the temperature range $280^{\circ} \mathrm{C}$ to $480{ }^{\circ} \mathrm{C}$, while for higher temperatures, aluminium oxide $\left(\mathrm{Al}_{2} \mathrm{O}_{3}\right.$, alumina) is the most stable form $(3)[11,13]$. For each of these reactions, the same amount of hydrogen is produced, the main differences are: required quantity of water, form of the oxidized aluminium and reaction

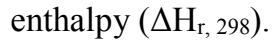

$$
\begin{aligned}
2 \mathrm{Al}(\mathrm{s})+6 \mathrm{H}_{2} \mathrm{O}(\mathrm{l}) & \rightarrow 2 \mathrm{Al}(\mathrm{OH})_{3}(\mathrm{~s})+3 \mathrm{H}_{2}(\mathrm{~g}) \\
\Delta \mathrm{H}_{\mathrm{r}, 298} & =-839 \mathrm{~kJ} / \mathrm{mol} \\
2 \mathrm{Al}(\mathrm{s})+4 \mathrm{H}_{2} \mathrm{O}(\mathrm{l}) \rightarrow 2 \mathrm{AlO}(\mathrm{OH})(\mathrm{s})+3 \mathrm{H}_{2}(\mathrm{~g}) & \\
\Delta \mathrm{H}_{\mathrm{r}, 298} & =-862 \mathrm{~kJ} / \mathrm{mol} \\
2 \mathrm{Al}(\mathrm{s})+3 \mathrm{H}_{2} \mathrm{O}(\mathrm{l}) \rightarrow \mathrm{Al}_{2} \mathrm{O}_{3}(\mathrm{~s})+3 \mathrm{H}_{2}(\mathrm{~g}) & \\
\Delta \mathrm{H}_{\mathrm{r}, 298} & =-950 \mathrm{~kJ} / \mathrm{mol}
\end{aligned}
$$

All three reactions are thermodynamically possible from room temperature until the melting point of aluminium $\left(660^{\circ} \mathrm{C}\right)$. However, aluminium surfaces oxidize rapidly in contact with air or water. The thin protective layer of aluminium oxide hinders the aluminium - water reaction under normal ambient conditions and in neutral water.

Several methods have been successfully investigated to induce and maintain the aluminium-water reaction by removal and/or disruption of the protective oxide, e.g.:

- $\quad$ using a promoter such as strong lyes: $\mathrm{NaOH}, \mathrm{KOH}$ (alkaline solutions) or $\mathrm{Ca}(\mathrm{OH})_{2}[14]$;

- grinding and milling aluminium just prior to the addition of water or while already mixed with water, or using ultrasonic procedures for the samples preparation $[15,16]$;

- $\quad$ using seawater with the addition of $\mathrm{NaAlO}_{2}$ [17];

- addition of Li-based [18] or choline hydroxide activators [19].

Sodium hydroxide $(\mathrm{NaOH})$ is considered the best alkali solution for enhancing the reaction rate and conversion degree $[7,9,10]$. The alkaline environment has the role to remove the natively formed protective oxide layer from the surface [20, 21]. Several authors have shown that aluminium reacts with water and $\mathrm{NaOH}$ (Eq. 4) and that $\mathrm{NaOH}$ is regenerated by the precipitation of $\mathrm{Al}(\mathrm{OH})_{3}$ (Eq. 5). The overall reaction (Eq. 6) is called the "aluminium-water reaction" [7, 14, 22].

$$
\begin{gathered}
2 \mathrm{Al}+6 \mathrm{H}_{2} \mathrm{O}+2 \mathrm{NaOH} \rightarrow 2 \mathrm{Na}\left[\mathrm{Al}(\mathrm{OH})_{4}\right]+3 \mathrm{H}_{2} \\
\mathrm{Na}\left[\mathrm{Al}(\mathrm{OH})_{4}\right] \rightarrow \mathrm{NaOH}+\mathrm{Al}(\mathrm{OH})_{3} \\
\left.2 \mathrm{Al}+6 \mathrm{H}_{2} \mathrm{O} \rightarrow 2 \mathrm{Al}(\mathrm{OH})_{3}\right]+3 \mathrm{H}_{2}
\end{gathered}
$$

Other reactions (Eq. 7 and 8) could occur between aluminium, sodium hydroxide and water:

$$
\begin{gathered}
2 \mathrm{Al}+2 \mathrm{H}_{2} \mathrm{O}+2 \mathrm{NaOH} \rightarrow \mathrm{Na}_{2} \mathrm{Al}_{2} \mathrm{O}_{4}+3 \mathrm{H}_{2} \\
2 \mathrm{Al}+\mathrm{xH}_{2} \mathrm{O}+6 \mathrm{NaOH} \rightarrow \mathrm{Na}_{6} \mathrm{Al}_{2} \mathrm{O}_{6}+\mathrm{xH}_{2} \mathrm{O}+3 \mathrm{H}_{2}
\end{gathered}
$$

Various devices and aluminium forms were reported for the aluminium - water reaction activated with sodium hydroxide $(\mathrm{NaOH})[7,14,22]$. Some authors used waste aluminium, e.g. from soft drink cans for obtaining hydrogen in the presence of sodium hydroxide $[22,23]$. Also, heavily adulterated scrap aluminium, which is not suitable for recycling and secondary aluminium production can be used for hydrogen production [24]. However, aluminium alloy composition may have an influence on the conversion degree [10].

In this paper, a seasonal energy storage cycle based on a controlled production of hydrogen via aluminium water reaction is proposed. The concept is first presented, followed by an example from the experimental parameters optimization. The influence of different aluminium shapes (grit, pellets and foil) on the amount of generated hydrogen and the reaction time is investigated.

\section{Heat and power storage using aluminium}

The development of a seasonal energy storage concept for heat and electricity production via aluminium-water reaction and fuel cells is performed in the Swiss project HybridStock. A feasibility study, including also a 
preliminary study of greenhouse gas emissions and primary energy consumption of the entire cycle (discharging and charging) was first carried out [25]. With this concept, the yearly heating and electricity demand could be covered by a solar and heat pump system combined with the aluminium based seasonal storage.

Compared to other storage media that are used or discussed for short and long-term energy storage, aluminium has the advantage of superior volumetric energy density (Fig. 3).

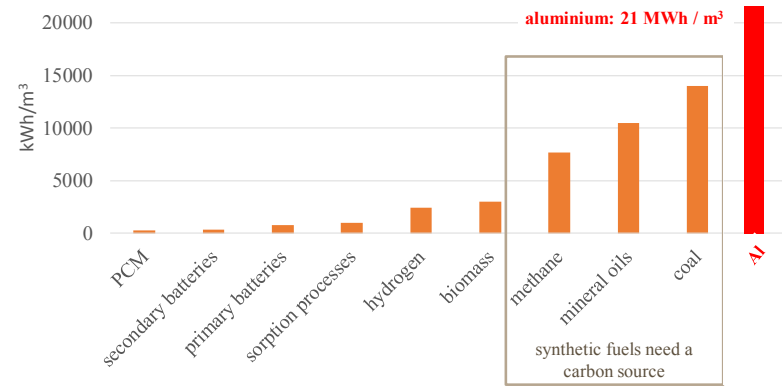

Fig. 3. Volumetric storage density of different materials (PCM $=$ phase change materials).

The unproblematic storability and transportability, the relative high concentration of this metal in the Earth's crust and the relative low cost make aluminium a promising energy storage material $[7,8,10]$.

From the reaction of aluminium with water at temperatures below $100{ }^{\circ} \mathrm{C}$, hydrogen, aluminium hydroxide and heat are produced (Fig. 4). According to the reaction stoichiometry, for each $\mathrm{kg}$ of aluminium, $0.1 \mathrm{~kg}$ of hydrogen can be obtained. Using this hydrogen in a fuel cell with an electric efficiency of $50 \%$ results in the generation of $2 \mathrm{kWh}_{\mathrm{el}}$ per $\mathrm{kg}$ of aluminium. An additional $6 \mathrm{kWh}_{\text {th }}$ of heat is produced in the aluminium - water reaction and with the fuel cell. Thus, the total energy density of aluminium as an energy storage medium is $8 \mathrm{kWh} / \mathrm{kg}$ or $21 \mathrm{MWh} / \mathrm{m}^{3}$.
The proposed concept (Fig. 5) includes a central processing plant at district level for charging the storage: here elementary aluminium is obtained from an Alsmelter that runs in summer with renewable electricity. At local/building level, hydrogen and heat are produced on demand in winter via aluminium - water reaction (discharging process). Hydrogen is immediately converted into electricity and heat with the fuel cell. Photovoltaics in combination with heat pump and conventional short-term storage systems provide electricity and heat to the building or to the central processing plant where aluminium is regenerated. PV electricity is used first for household appliances, while the heat pump is used for heating and domestic hot water preparation. Excess electricity in summer is supplied to the grid to be used for the Al smelter. A small Li-ion battery and thermal energy storage (TES) with water are used as short-term energy storage (in the range of days, up to a week).

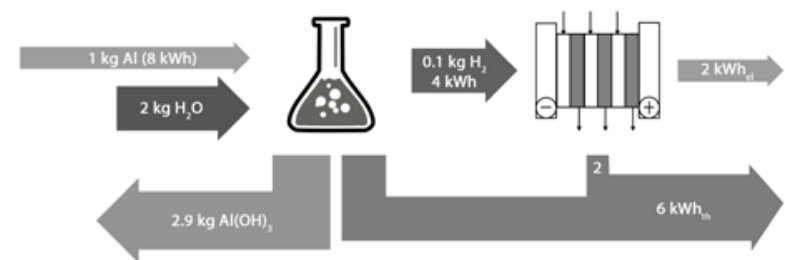

Fig. 4. Heat and electricity production via aluminium-water reaction that supplies hydrogen to fuel cells.

We are proposing this solution for $100 \%$ solar driven residential buildings (single family, multifamily or industrial buildings). From an economic perspective, for multifamily/industrial buildings it is more favourable because the investment cost per unit energy provided is expected to be much lower.

Considering our preliminary calculations [25], about $500 \mathrm{~kg}$ of aluminium could supply electricity and heat to a single family home for winter in combination with a $\mathrm{PV}$ and heat pump system.

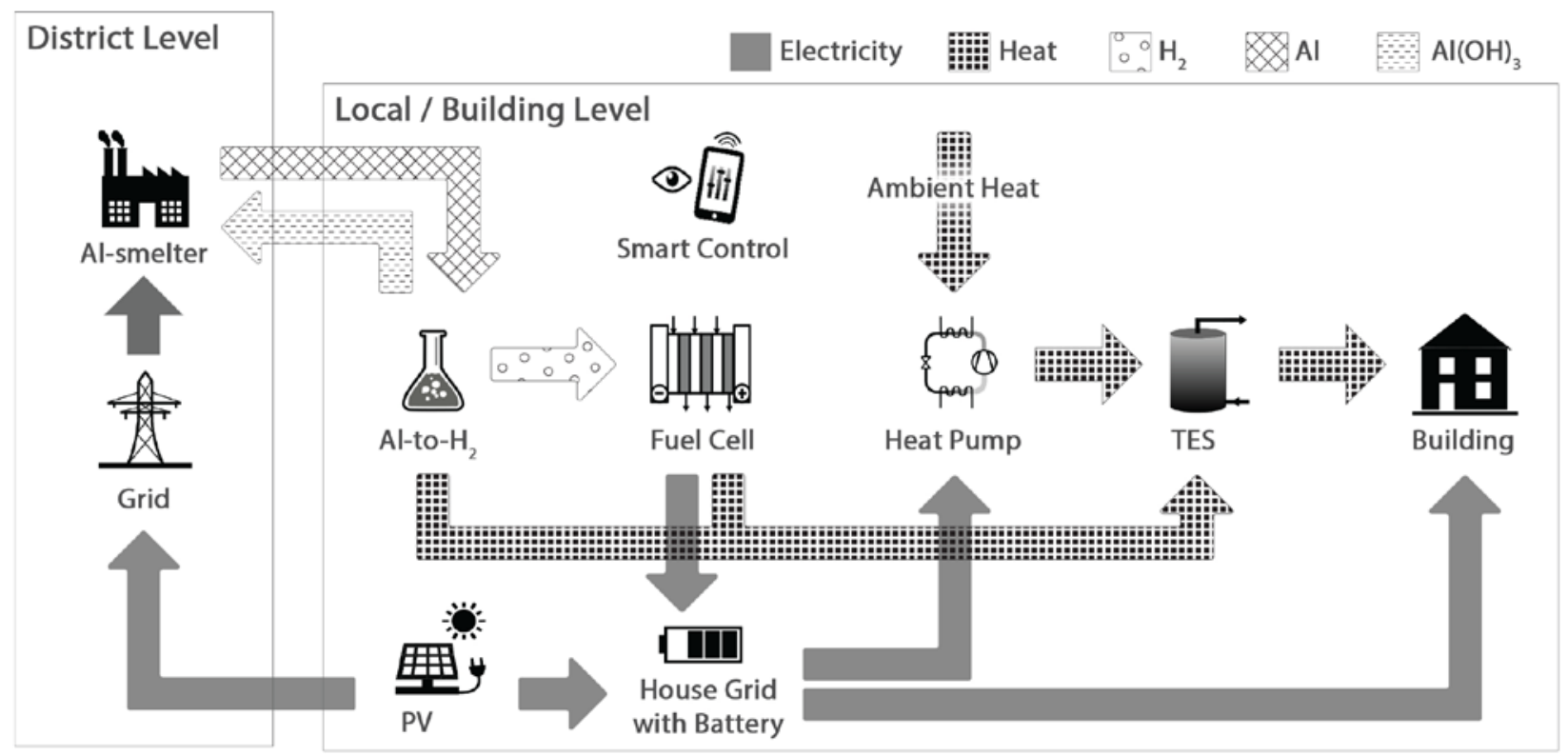

Fig. 5. Electricity and heat supply for $100 \%$ solar coverage with aluminium seasonal energy storage. 


\section{Experimental}

Aluminium samples of different shapes (Table 1) have been used as received: grit (particle size $<1 \mathrm{~mm}$ ), pellets (3-12 mm), pure foil (thickness of $0.25 \mathrm{~mm}$ ) and commercial foil (thickness of $0.013 \mathrm{~mm}$ ). All aluminium samples were supplied by Sigma-Aldrich and Merck, except for the commercial foil. The aqueous promoter's solutions have been freshly prepared from concentrated solution $(\mathrm{NaOH} 50$ wt.\%, Sigma-Aldrich) using deionized water as solvent.

Energy dispersive X-ray spectroscopy (EDX, JSM7100) was used to evaluate which metal impurities are in aluminium samples.

An ANKOM ${ }^{\mathrm{RF}}$ Gas Production System (Fig. 6) was used for investigating the efficiency of the aluminiumwater reaction. Hydrogen generation was evaluated by monitoring the gas pressure and temperature. Four experiments were performed in parallel for statistics purpose. Aluminium samples were introduced via a gelatine capsule in the reactor. After placement of the capsule, the bottle was closed and the increase in pressure was monitored. A blind probe of gelatine capsule without content did not lead to a measurable pressure increase. The optimal reaction parameters (temperature, concentration and volume of the reaction promoter, solvent type) were investigated and reported elsewhere [26].

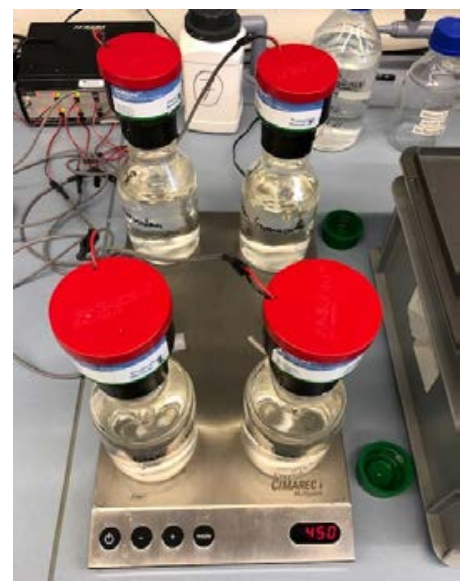

Fig. 6. Experimental setup for testing the influence of different aluminium shapes.

\section{Results and discussion}

The efficiency of aluminium conversion to hydrogen depends on several variables such as composition, form and morphology of aluminium sample, reaction temperature or promoter's concentration.

\subsection{Composition of the aluminium samples}

Energy dispersive X-ray spectroscopy was used for composition characterization and identification of other metals present in the samples. Besides aluminium, Fe, Mn, Ni, Ti were found (Table 1). Among these, Fe could react with sodium hydroxide and water. At higher temperature (in a boiling solution) and no oxygen, tetrahydroxoferrate(II) sodium and hydrogen may be formed (Eq. 9). In the presence of oxygen and concentrated aqueous sodium hydroxide solutions, oktahydroxoferrate(III) sodium could be obtained (Eq. 10) at room temperature [27].

$$
\begin{gathered}
\mathrm{Fe}+2 \mathrm{NaOH}+2 \mathrm{H}_{2} \mathrm{O} \rightarrow \mathrm{Na}_{2}\left[\mathrm{Fe}(\mathrm{OH})_{4}\right]+\mathrm{H}_{2} \\
4 \mathrm{Fe}+20 \mathrm{NaOH}+3 \mathrm{O}_{2}+6 \mathrm{H}_{2} \mathrm{O} \rightarrow 4 \mathrm{Na}_{5}\left[\mathrm{Fe}(\mathrm{OH})_{8}\right]
\end{gathered}
$$

Table 1. Aluminium samples and metal impurities evaluated via energy dispersive X-ray spectroscopy.

\begin{tabular}{|l|c|}
\hline Sample & Metal impurities \\
\hline Grit & $\mathrm{Fe}, \mathrm{Ti}$ \\
\hline Al pellet & $\mathrm{Fe}, \mathrm{Ni}$ \\
\hline Al-foil $0.013 \mathrm{~mm}$ (commercial) & $\mathrm{Fe}, \mathrm{Mn}$ \\
\hline Al-foil $0.25 \mathrm{~mm}$ (pure) & - \\
\hline
\end{tabular}

\subsection{Influence of the aluminium shape on the amount of hydrogen and reaction time}

Several experiments were carried out using the $\mathrm{ANKOM}^{\mathrm{RF}}$ Gas Production System in order to study the influence of the morphology / shape of the aluminium on the hydrogen production rates. The optimum process parameters previously reported were used [26], only the aluminium form was varied.

The results from Fig. 7 indicate that the Al shape has not a significant influence on the total $\mathrm{H}_{2}$ volume that was produced. The amount of hydrogen is similar for all aluminium types; the small differences may be due to purity and measurement uncertainty. As the experiments were performed at room temperature and the solutions were not degassed, we assume that hydrogen is obtained only from the aluminium-water reaction (Eq. 4) and not also from the iron reaction from Eq. 9.

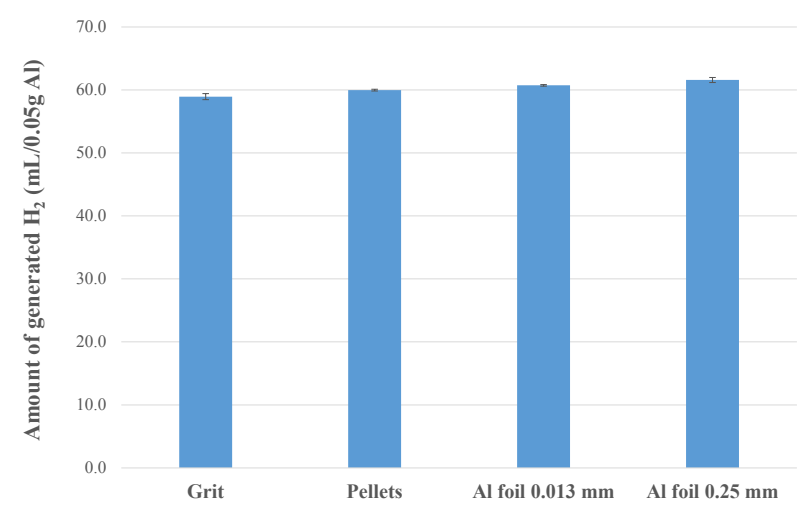

Fig. 7. Effect of the aluminium shape on the total volume of $\mathrm{H}_{2}$ produced $(0.05 \mathrm{~g}$ of aluminium and $6 \mathrm{M} \mathrm{NaOH}$ at room temperature).

The hydrogen flow rate was calculated from the data from Fig. 8 and it is shown in Table 2. 
Table 2. Influence of aluminium shape on reaction efficiency.

\begin{tabular}{|c|c|c|c|c|}
\hline Parameter & Grit & Pellet & Al-foil 0.013 mm & Al-foil 0.25 mm \\
\hline $\mathbf{V}_{\mathbf{H} 2 \text { /0.05gAl (mL) }}$ & $58.9 \pm 0.5$ & $60.0 \pm 0.1$ & $60.7 \pm 0.1$ & $61.6 \pm 0.4$ \\
\hline Efficiency (\%) & $95.3 \pm 3.8$ & $97.0 \pm 3.5$ & $98.2 \pm 3.6$ & $98.1 \pm 3.8$ \\
\hline Reaction time* (min) & $37.0 \pm 1.7$ & $948.4 \pm 68.3$ & $3.2 \pm 0.9$ & $259.4 \pm 4.6$ \\
\hline Maximum $\mathbf{H}_{\mathbf{2}}$ flow rate (10) $\mathbf{~ m L / s e c ) ~}$ & $140 \pm 2$ & $2.0 \pm 0.2$ & $1600 \pm 200$ & $4.10 \pm 0.05$ \\
\hline
\end{tabular}

The flow rate is an important design parameter for the energy conversion unit. The lowest value was recorded for the pellet, while the maximum value was reached in the case of the thin Al foil. For this Al form (foil $0.013 \mathrm{~mm}$ ), the reaction takes place very fast. A rather similar behaviour was registered for the grit and the thicker $\mathrm{Al}$ foil. These types of $\mathrm{Al}$ forms could be used in case of a quick energy demand (e.g. hot water for shower). On the other hand, pellets are reacting slowly, over a longer period. This would be the optimum "Al fuel" for space heating.

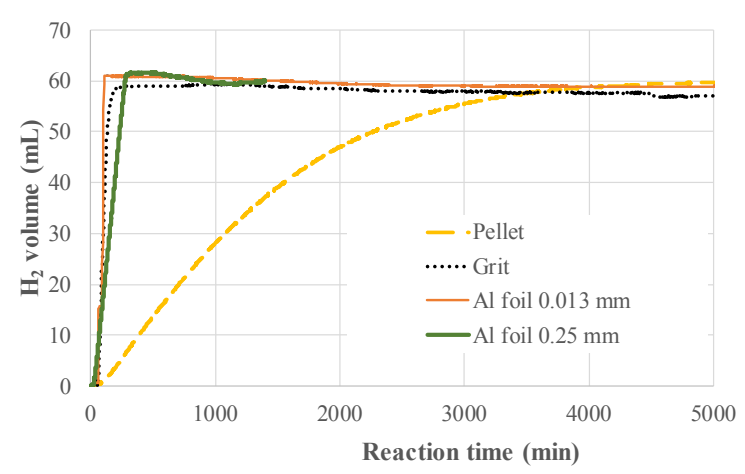

Fig. 8. Volume of $\mathrm{H}_{2}$ produced for different aluminium forms ( $0.05 \mathrm{~g}$ of aluminium and $6 \mathrm{M} \mathrm{NaOH}$, room temperature).

The flow rate depends on the available surface area for the reaction, as all other process parameters were kept constant. The geometrical surface area per weight was calculated for each type of aluminium form. A perfect sphere was assumed for grit and pellets. As can be seen in Fig. 9, the higher the specific surface area is, the faster is the reaction and the lower is the reaction time. Thus, reaction time, reaction rate and flow rate can be correlated with the specific surface area.

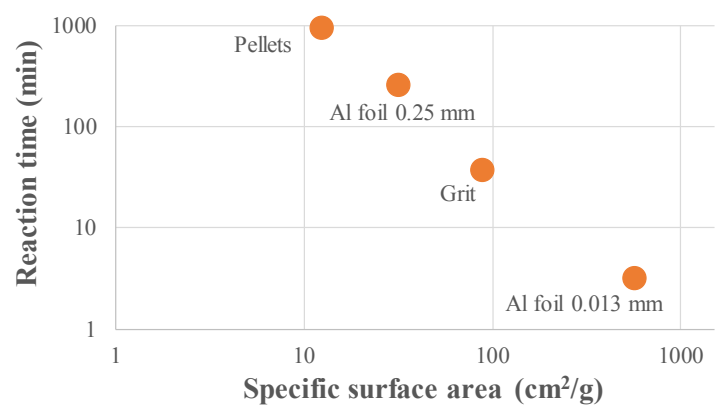

Fig. 9. Effect of the specific surface of the aluminium on the reaction time $(0.05 \mathrm{~g}$ of aluminium and $6 \mathrm{M} \mathrm{NaOH}$ at room temperature).

\section{Conclusions and further work}

For the mitigation of climate change and in order to reach the target of keeping global warming below $2 \mathrm{~K}$ on average, more efforts and more stringent targets will be needed. Solar energy is expected to contribute significantly to the decarbonization of the electricity and heat production. However, being abundantly available in summer and scarce in winter when more energy is needed to supply heat for space heating, the potential of solar energy utilization is hindered by a lack of suitable, energy and cost efficient, seasonal storage technologies.

A new concept of seasonal energy storage based on a redox cycle of aluminium $\mathrm{Al} \rightarrow \mathrm{Al}^{3+} \rightarrow \mathrm{Al}$ is proposed. The oxidation process $\left(\mathrm{Al} \rightarrow \mathrm{Al}^{3+}\right)$ takes place in the presence of water and a reaction promoter like sodium hydroxide. This highly exothermic reaction generates hydrogen on demand, and also heat and aluminium hydroxide as a by-product. Hydrogen is not stored, but supplied to a fuel cell to produce instantaneously electricity and heat. This oxidation process is the discharging phase and it is intended for delivering heat and power to low and zero energy buildings or industrial processes. During charging (reduction process $\mathrm{Al}^{3+} \rightarrow \mathrm{Al}$ ), electricity from renewables is used to regenerate the aluminium from aluminium hydroxide $->$ aluminium oxide (alumina) -> elementary aluminium, in a district plant. A joint venture of Rio Tinto \& Alcoa named Elysis announced in May 2018 that inert aluminium smelters will be available on the market starting with 2024. If inert electrode smelter processes are used for alumina reduction to aluminium, carbonneutral aluminium can be provided to buildings for heat and power storage.

The discharging phase of this seasonal energy storage has been analysed and demonstrated in the laboratory. The aluminium-water reaction produced heat and hydrogen reliably and with high efficiency of the stoichiometric production of hydrogen, irrespective of the type and shape of aluminium that was used.

The production of aluminium from alumina consumes a lot of energy, which is usually seen as an ecological disadvantage of this material. However, if a large fraction of this energy can be released again via aluminium-water reaction, which creates large amounts of heat and hydrogen, then it is an excellent energy storage material. According to our calculations, about $500 \mathrm{~kg}$ of aluminium could supply electricity and heat to a single family home for winter in combination with a $\mathrm{PV}$ and heat pump system. 
Further steps will include the combination with a fuel cell and a laboratory setup that will be able to produce heat and electricity continuously.

We gratefully acknowledge the support of Swiss Federal Office of Energy (SFOE) in the frame of the project HybridStock (SI/501693-01) and of the HSR University of Applied Sciences of Rapperswil.

\section{References}

1. European Commission, Energy roadmap 2050 (Publications Office of the European Union, Luxembourg, 2012)

2. European Commission, Heating and Cooling In the European Energy Transition - Challenges and Facts (European Commission, Brussels, 2015)

3. M. Haller, Solar Energy and Heat Pumps - Short Term (and Long Term) Storage Options, presented at the EuroSun 2018 Conference, Rapperswil, Switzerland, 2018

4. S. Kalaiselvam and R. Parameshwaran, Chapter 7 Seasonal Thermal Energy Storage (Thermal Energy Storage Technologies for Sustainability, Academic Press, Boston, 2014)

5. J. Jenni, Das Sonnenhaus - mit hohem solarem Deckungsgrad für Warmwasser und Heizung (3. Auflage, Jenni Energietechnik AG, Oberburg bei Burgdorf, 2010)

6. C. Luterbacher, The Swiss houses making energy go a long way, SWI swissinfo.ch, 2016, https://www.swissinfo.ch/eng/business/fallingemissions the-swiss-houses-making-energy-go-along-way/41977836 (Accessed: 01-Feb-2019)

7. L. Soler, A. M. Candela, J. Macanás, M. Muñoz, and J. Casado, J. Power Sources 192, 21 (2009)

8. H. Z. Wang, D. Y. C. Leung, M. K. H. Leung, and M. Ni, Renew. Sustain. Energy Rev 13, 845 (2009)

9. X. Huang et al., J. Power Sources 229, 133 (2013)

10. E. I. Shkolnikov, A. Z. Zhuk, and M. S. Vlaskin, Renew. Sustain. Energy Rev. 15, 4611 (2011)

11. D. Belitskus, J. Electrochem. Soc. 117, 1097 (1970)

12. P. L. Miller and A. Navarro, Hazardous reactions of aluminum powder with water in the propellant, explosive and pyrotechnic (PEP) industries (Alliant Techsystems Inc Hopkins Mn, 1996)

13. F. Franzoni, M. Milani, L. Montorsi, and V. Golovitchev, Int. J. Hydrog. Energy 35, 1548 (2010)

14. E. R. Andersen and E. J. Andersen, US2003/0143155 A1, 2003

15. Y. Yang, W.-Z. Gai, Z.-Y. Deng, and J.-G. Zhou, Int. J. Hydrog. Energy 39, 18734 (2014)

16. B. Alinejad and K. Mahmoodi, Int. J. Hydrog. Energy 34, 7934 (2009)

17. L. Soler, A. M. Candela, J. Macanas, M. Munoz, and J. Casado, Int. J. Hydrog. Energy 34, 8511 (2009)

18. S. Elitzur, V. Rosenband, and A. Gany, Int. J. Appl 5, $112(2015)$

19. H. Wang, Z. Wang, Z. Shi, X. Gong, J. Cao, and M. Wang, Energy 131, 98 (2017)
20. H.-T. Teng, T.-Y. Lee, Y.-K. Chen, H.-W. Wang, and G. Cao, J. Power Sources 219, 16 (2012)

21. Y. Yavor, S. Goroshin, J. M. Bergthorson, D. L. Frost, R. Stowe, and S. Ringuette, Int. J. Hydrog. Energy 38, 14992 (2013)

22. S. Martínez, W. López Benítes, A. Álvarez Gallegos, and P. J. Sebastián, Sol. Energy Mater. Sol. Cells 88, 237 (2005)

23. T. Hiraki and T. Akiyama, Int. J. Hydrog. Energy 34, 153 (2009)

24. E. Elsarrag, A. Elhoweris, and Y. Alhorr, Energy Sustain. Soc. 7, 9 (2017)

25. M. Haller, D. Carbonell, M. Dudita, and D. Zenhäusern, HePoStAl - Heat and Power Storage in Aluminum (Swiss Federal Office of Energy SFOE, Bern, 2018)

26. M. Haller et al., 100\% Solar energy for heating and electricity all year around by a solar and heat pump system combined with aluminium redox seasonal storage, presented at the International Renewable Energy Storage Conference (IRES 2019), Düsseldorf, Germany, 2019

27. L. Pataki and E. Zapp, Basic Analytical Chemistry (Elsevier, 2013) 